ment that these benefits are beginning to tum into a burden. Rolland Dewing

Chairman, Division of

Social Sciences,

Chadron State College, Neb.

Noel Perrin Responds:

Mr. Dewing has a good point, that one should not renounce things on behalf of other people. An American who owns a car, as I do (a truck, anyway), looks rather odd telling Malays they will be happiest if they keep their water buffalo.

Mr. Dewing's main point, however, that industrialization and progress have always produced net benefits for the common man-and still do-will not bear scrutiny. The examples he offers are Westem Europe, the United States, and Japan. Of course industrialization has produced benefits in all three places, or it would not have occurred. But if Mr. Dewing cares to examine the quality of life in England, say, in 1772 and then in 1972, what will he find? He will find that the $\mathbf{5 0}$ million Englishmen now living do indeed have better medical care, a higher literacy rate, faster means of getting from London to Brighton. But he will also find that the 7 million Englishmen living in 1772 had a better diet-or at least one more to their taste-since present luxuries such as lobsters, oysters and roast beef were then available to the common man. He will also find that they had somewhat more sunlight (yes, literally), a humane noise level, easy access to open countryside, etc. etc.

As for Japan, the great Japanese scholar at Columbia, Ivan Morris, has remarked that it took the Japanese about 2,000 years to ereate their landscape and one generation (194572 ) to destroy it. Certainly it is true that the Japanese are moving from farm to factory. How much choice is involved is another matter. I myself would explain a good deal of the move by the fact that because of industrialization it is no longer possible for most small farmers to make a comfortable living. Did American blacks want to leave the rural South and move to urban ghettos? Yes, plainly they sometimes did. But I do not think Mr. Dewing can safely ignore the role played by cottonpicking machinery, by the battery chicken farm (which ended pin money for the black farmer's wife with thirty hens), by the effects tractors have had on mules.

The example I want to end with, though, is India. Mr. Dewing thinks that "people looking back will see our day as one of a rapid increase in the well-being of the world's dispossessed." I presume he would agree with me that the most dispossessed large population in the world is to be found in Calcutta and throughout India. Are people there enjoying a rapid increase in wellbeing? Not in their own estimation. I once heard the Indian ambassador to the U.S. make a speech to a large audience of American doctors in which he blamed most of the ills of India on Western science in general and English and American doctors in particular. He gave them credit for good and sometimes even noble intentions. But their intentions didn't alter the facts, he said. Which were (I quote from memory) that India in $1750 \mathrm{had}$ a stable population of 150 million, enough food to go around, and sufficient surplus wealth to attract the avarice of both England and France. Then British government doctors and English and American medical missionaries began to introduce a rather lopsided "progress" in death control. So that now there are around 500 million Indians, a large proportion of them underfed, underhoused, undereverything. Some advance.

If Mr. Dewing can really look at India (or Puerto Rico or Tahiti or New Jersey) and say that the lower class in these places is better off than it was a century ago, then he and I have very different ideas indeed of what it is to be well off.

\section{African Literature}

To the Editors: One cannot help but feel distressed at how "black" a picture Kof Awoonor draws of current African politics and ideology ("Africa's Literature Beyond Politics," March). . . . His account of the genesis of négritude is accurate. But négritude has spawned a brood of interests in black cultural values, and some of these have proved both scientific and salutary. (I have in mind current interest in the nexus of cultural continuity between Africa and the "New World.")

More crucial is Awoonor's view of pessimism in the post-colonial African novel, and his dichotomy of (either?) political crusading and (or?) illuminating life for all people. There is much in current or past African life worthy of disillusionment, sadness and anger, and sometimes the culprits are identifiable. All these can be mentioned, even stressed, without despair. They are, for example, in Peter Palangyo's Dying in the Sun and Robert Serumaga's Return to the Shadows. Is description of the negative without proposing a program pessimism; is "fingering" the causes political crusading? Furthermore, there are novels of traditional (Legson Kayira's Jingala), colonial (Mongo Beti's King Lazarus) and independent life (Gabriel Ruhumbika's Village in Uhuru) full of criticism, love and joy.

Many of my examples may be taken as too "light" for comparison with works of Armah, Awoonor or Soyinka. Such dismissal will automatically distort our view of African literature. Furthermore it implies criteria of form and (individualistic) content derived from Euro-America's haute cuisine of Kultur. African novelists most attuned to this esthetic do indeed produce Fragments or Voices in the Dark-the Western fashion.

Most literature which has appealed to the world at large was written to, for, and of a parochial culture; most written to illuminate life for all people has been uninspired nonsense. Let us reject even veiled calls to universalism. It is the reader's job to be "universal," to find illumination in books not written with him in mind. How distressing it would be if Western readers accepted only familiar, psychedelic light from black Africa.

Department of Classics,

David F. Dorsey, Jr.

New York University 